\title{
Association between a non-synonymous HSD17B4 single nucleotide polymorphism and meat-quality traits in Berkshire pigs
}

\author{
J.L. Jo ${ }^{1 *}$, J.H. Hwang ${ }^{1 *}$, S.G. Kwon ${ }^{1}$, D.H. Park ${ }^{1}$, T.W. Kim ${ }^{1}$, D.G. Kang ${ }^{1}$, \\ G.E. Yu ${ }^{1}$, I.S. Kim ${ }^{2}$, J. $\mathrm{Ha}^{1}$ and C.W. Kim ${ }^{1}$ \\ ${ }^{1}$ Swine Science and Technology Center, \\ Gyeongnam National University of Science \& Technology, Jinju, South Korea \\ ${ }^{2}$ Department of Animal Resource Technology, \\ Gyeongnam National University of Science \& Technology, Jinju, South Korea \\ *These authors contributed equally to this study. \\ Corresponding authors: J. Ha / C.W. Kim \\ E-mail: jiha@gntech.ac.kr / cwkim@gntech.ac.kr
}

Genet. Mol. Res. 15 (4): gmr15048970

Received July 14, 2016

Accepted August 31, 2016

Published November 3, 2016

DOI http://dx.doi.org/10.4238/gmr15048970

Copyright (C) 2016 The Authors. This is an open-access article distributed under the terms of the Creative Commons Attribution ShareAlike (CC BY-SA) 4.0 License.

\begin{abstract}
Single nucleotide polymorphisms (SNPs) are useful genetic markers that allow correlation of genetic sequences with phenotypic traits. It is shown here that HSD17B4, a bifunctional enzyme mediating dehydrogenation and anhydration during $\beta$-oxidation of long-chain fatty acids, contains a non-synonymous SNP (nsSNP) of chr2:128,825,976A>G, c.2137A $>$ G, I690V, within the sterol carrier protein-2 domain of the HSD17B4 gene, by RNASeq of liver RNA. The HSD17B4 mRNA was highly expressed in the kidney and liver among various other tissues in four pig breeds, namely, Berkshire, Duroc, Landrace, and Yorkshire. The
\end{abstract}

Genetics and Molecular Research 15 (4): gmr15048970 
nsSNP was significantly associated with carcass weight, backfat thickness, and drip loss $(\mathrm{P}<0.05)$. Furthermore, HSD17B4 may play a crucial role during the early stages of myogenesis when expression of its mRNA was significantly high. In conclusion, HSD17B4 may serve as a possible regulator of muscle development, and its identification should help to select for improved economic traits of Berkshire pigs such as carcass weight, backfat thickness, and drip loss.

Key words: Berkshire pig; HSD17B4; Single nucleotide polymorphisms; Meat-quality trait

\section{INTRODUCTION}

Hydroxysteroid (17-beta) dehydrogenase 4 (HSD17B4) is a bifunctional enzyme associated with $\beta$-oxidation of long fatty acids or fatty acid derivatives in peroxisomes. This enzyme consists of an L-3-hydroxyacyl-CoA dehydrogenase domain in its N-terminus, an enoyl-CoA hydratase domain in the intermediate region of the partial $\mathrm{C}$-terminus, and a sterol carrier protein (SCP)-2 domain in its C-terminus (Breitling et al., 2001; Moeller and Adamski, 2009). The SCP-2 domain interacts with a variety of long chain fatty acids that are substrates for HSD17B4 (Colles et al., 1995; Dansen et al., 1999; Ferreyra et al., 2006), but the domain itself does not bind with fatty acids that are not substrates (Stolowich et al., 1997; García et al., 2000). The SCP-2 domain may function as a transport/uptake protein that carries lipids between the membrane and other lipid-containing materials. Mice deficient in SCP-2 exhibit defects in the degradation of cholesterol, bile lipids, and branched fatty acids (Seedorf et al., 1998).

17-Beta-hydroxysteroid dehydrogenase $(17 \beta-H S D)$ mediates the physiological function of androgens and estrogens by catalyzing the interconversion of active and inactive forms of steroids (Baker, 2001). Although $17 \beta$-HSD activity is several times lower than that of $\beta$-oxidation in HSD17B4, its $\beta$-oxidation activity has not been fully addressed. Expression of the $17 \beta$-HSD protein is regulated by steroids, including progesterone, in the kidney and uterus (Kaufmann et al., 1995). Inducing HSD17B4 in Duroc pigs leads to high levels of androstenone in the testicles (Moe et al., 2007) and in the liver (Moe et al., 2008). Because liver includes many proteins that regulate androstenone and plays a role in steroid homeostasis, the liver has been hypothesized to be closely associated with male odor and meat traits. Therefore, it can be deduced that HSD17B4, which regulates steroid activity, is an enzyme that is accompanied by various proteins and pathways important to meat quality.

In recent years, many researchers have been focused on the identification of SNPs and the expression profile of candidate genes that might have close association with meat quality (Chai et al., 2015; Wu et al., 2015). Finally, they put their effort to adjust these results in breeding for improved economic traits in pig industry (Cho et al., 2015a).

In the present study, we examined the expression of HSD17B4 mRNA from various tissues of four pig breeds: Berkshire, Duroc, Landrace, and Yorkshire. The association between pork quality traits and $H S D 17 B 4$ genotypes was analyzed through SNP analysis. Finally, the expression of HSD17B4 was investigated with the intent of characterizing its role during myogenesis.

Genetics and Molecular Research 15 (4): gmr15048970 


\title{
MATERIAL AND METHODS
}

\begin{abstract}
Animals
A total of 377 pigs from the Baekdusan pedigree line (Dasan Genetics, Namwon, Korea) were reared under identical conditions and fed with commercial feeds according to the regimes of Purina Ltd. Pigs were bred and then slaughtered in 10 batches when their body weights reached $110 \mathrm{~kg}$ (males, 186, all castrated; females, 191).
\end{abstract}

\section{Carcass trait analyses}

The Berkshire pigs were slaughtered by electrocution with electrical tongs ( $300 \mathrm{~V}$ for $3 \mathrm{~s}$ ) after $12 \mathrm{~h}$ of feed restriction. The carcasses were placed in a dehairer at $62^{\circ} \mathrm{C}$ for $5 \mathrm{~min}$ and any remaining hair was removed using a knife and flame following exsanguination. Carcasses were eviscerated and split before being placed in a chiller set at $2^{\circ}-4^{\circ} \mathrm{C}$ for $12 \mathrm{~h}$. Various meat-quality traits including carcass weight, backfat thickness, meat color (lightness, redness, and yellowness), drip loss, cooking loss, chemical composition (collagen, fat, moisture, and protein), water holding capacity, shear force, and post-mortem $\mathrm{pH} 24 \mathrm{~h}$ (measurement of $\mathrm{pH}$ after $24 \mathrm{~h}$ of slaughter) were measured (Cho et al., 2015b).

Backfat thickness was measured on the 10th rib region positioned at three-quarters distance along the longissimus thoracis (LT) toward the belly, within $30 \mathrm{~min}$ of slaughter. The concentrations of moisture, crude protein, and crude fat from the LT muscles were determined according to the methods of the Association of Official Analytical Chemists (AOAC, 2006) in muscle samples taken $24 \mathrm{~h}$ after slaughter. Collagen content was measured as previously described (Cho et al., 2015b). The LT (6th to 13th rib) was excised and stored at $2^{\circ}-4^{\circ} \mathrm{C}$ before it was transported to the laboratory to determine the chemical composition (Cho et al., 2015b).

Meat and fat color were recorded after $30 \mathrm{~min}$ blooming at $1^{\circ} \mathrm{C}$ by using a Minolta Chromameter (CR400; Minolta, Japan) with $8 \mathrm{~mm}$ in aperture size, illuminant D65, a $2^{\circ}$ closely matches CIE1931 standard observer, and measurement/illumination of $\phi 8 / \phi 11 \mathrm{~mm}$. The instrument was standardized using white plate $\left(\mathrm{L}^{*}=+97.83, \mathrm{a}^{*}=-0.43, \mathrm{~b}^{*}=+1.98\right)(\mathrm{Cho}$ et al., 2015b).

The drip loss was measured as the percentage weight loss of a standardized $(3 \times 3 \times$ $3 \mathrm{~cm}$ ) LT muscle sample placed on a sealed Petri dish at $4^{\circ} \mathrm{C}$ for 2 days. A 3-cm thick slice (weight $100 \pm 5 \mathrm{~g}$ ) separated from the LT muscle was used to measure cooking loss. LT muscle was placed into a polypropylene bag, cooked for $40 \mathrm{~min}$ at $70^{\circ} \mathrm{C}$ in a water bath, and then cooled to room temperature. Cooking loss was calculated by the weight difference before and after heating (Cho et al., 2015b).

The water holding capacity was determined according to a previously described method (Kristensen and Purslow, 2001). Warner-Bratzler shear force was measured using LT muscle, which was allowed to thaw to room temperature for about $2 \mathrm{~h}$ before measurement using 5 cores $(1.23 \mathrm{~cm}$ in diameter) following the direction of the fibers and sheared at a crosshead speed of $240 \mathrm{~mm} / \mathrm{min}$ (Cho et al., 2015b).

The post-mortem $\mathrm{pH} 24 \mathrm{~h}$ was measured using $10 \mathrm{~g} \mathrm{LT}$ muscle that was stored at $4^{\circ} \mathrm{C}$ for $24 \mathrm{~h}$. The LT muscle was cut into small pieces to which $90 \mathrm{~mL}$ distilled water was added and an slurry was made using a homogenizer (T25B, IKA Sdn, Bhd., Malaysia). The post-mortem pH $24 \mathrm{~h}$ of the slurry was then measured using a digital $\mathrm{pH}$ meter (8603, Metrohm, Swiss).

Genetics and Molecular Research 15 (4): gmr15048970 


\section{Identification of the non-synonymous SNP (nsSNP) by RNA-Seq and genotyping}

Total RNA from liver tissue was isolated using an RNA-Seq sample preparation kit as previously described (Illumina, Inc., San Diego, CA, USA) (Gispert et al., 2010). The SNP was identified as previously described (Jung et al., 2012). The nsSNP within the HSD17B4 gene was identified as rs 81216713 using the dbSNP database. Genomic DNAs were isolated using the Wizard Genomic DNA Purification kit (Promega, Madison, WI, USA) from individual LT muscles of Berkshire pigs. To analyze the association between the nsSNP in the HSD17B4 gene and pork quality traits, genomic DNAs of 377 Berkshire LT muscles were employed using a Veracode GoldenGate assay kit (Illumina). Oligonucleotides utilized for genotype analyses are indicated in Table 1.

Table 1. Summary for analyses of genotypes and oligonucleotides used for RT-PCR.

\begin{tabular}{l|l|l}
\hline \multicolumn{2}{l|}{ Locus } & $c .2137 A>G$ \\
\hline $\begin{array}{l}\text { Oligo-nucleotides for } \\
\text { genotyping }\end{array}$ & Allele-frequency & $\begin{array}{l}\text { G: } 0.601 \\
\text { T: } 0.399\end{array}$ \\
\cline { 2 - 3 } & $\begin{array}{l}\text { Allele-specific } \\
\text { Oligo 1 }\end{array}$ & 5'-ACTTCGTCAGTAACGGACAAGGTTCTGCTGATGCAACCTTCA-3' \\
\cline { 2 - 3 } & $\begin{array}{l}\text { Allele-specific } \\
\text { Oligo 2 }\end{array}$ & 5'-GAGTCGAGGTCATATCGTAAGGTTCTGCTGATGCAACCTTCG-3' \\
\cline { 2 - 3 } & $\begin{array}{l}\text { Allele-specific } \\
\text { Oligo 3 }\end{array}$ & 5'-ACTTTCGGATGAAGTTTTCATACGGTCCACTACTCGATGCGCTGTCTGCCTATAGTGAGTC-3' \\
\hline
\end{tabular}

\section{RT-qPCR amplification}

To investigate the mRNA expression of HSD17B4 in various tissues of Berkshire, Duroc, Landrace, and Yorkshire pigs, total RNA was isolated from liver, stomach, lung, kidney, large intestine, small intestine, and spleen of three female pigs using TRI Reagent ${ }^{\mathbb{B}}$ according to the manufacturer's protocol (Molecular Research Center, Cincinnati, OH, USA). To elucidate the mRNA expression of marker genes for myogenesis, total RNA was prepared from $\mathrm{C} 2 \mathrm{C} 12$ (mouse myoblast) cells. The quality of isolated RNA was measured as $\mathrm{A}_{260} / \mathrm{A}_{280}$ $>1.8$. The mRNA (500 ng) was reverse-transcribed into cDNA using Superscript II (Invitrogen, Carlsbad, CA, USA) in a total reaction volume of $20 \mu \mathrm{L}$.

Gene-specific exon spanning primers against pig and mouse HSD17B4, genes that were used for normalization (PPIA, TBP, TOP2B, RPL4, and RPS18 for pig and GAPDH for mouse), and genes associated with myogenesis ( $M y o D, M y o G$, and $M y H C-2 B)$ were designed using the Primer3 program (http://frodo.wi.mit.edu/primer3/; Table S1) (Rozen and Skaletsky, 2000). BLASTs were performed to confirm gene specificity of the primer sequences, and the results showed the absence of multi-locus matching at individual primer sites. Standard curves were determined by increasing the quantity of template DNA, a t-vector clone created with RT-PCR products from each gene. Amplification efficiencies and correlation coefficients $\left(\mathrm{R}^{2}\right.$ values) were measured using the slopes of the standard curves obtained from the serial dilutions. Standard curves with a 10 -fold dilution series were used to calculate amplification efficiency according to the following formula: efficiency $(\%)=\left(10^{(-1 / \text { lope })}-1\right) \times 100$. The range of efficiency of the real-time RT-PCR amplifications was $88-99 \%$.

RT-qPCR was performed using SYBR Green Chemistry with a Rotor Gene Q thermocycler (Qiagen). For each reaction, $1 \mu \mathrm{L}$ cDNA (500 ng RNA was used for reverse 
transcription in a total volume of $20 \mu \mathrm{L}$ ) was used as a template and added to a $19-\mu \mathrm{L}$ reaction mixture containing $7 \mu \mathrm{L} \mathrm{H}_{2} \mathrm{O}, 10 \mu \mathrm{L}$ Rotor Gene SYBR Green PCR mastermix (Qiagen), and $1 \mu \mathrm{L}$ each of forward and reverse primer (10 pmol). Real-time RT-PCR amplification was performed as described previously (Park et al., 2015). In brief, PCR conditions were as follows: 40 cycles at $94^{\circ} \mathrm{C}$ for $5 \mathrm{~s}$ and $60^{\circ} \mathrm{C}$ for $10 \mathrm{~s}$. The melting curve, performed at $70^{\circ}$ to $95^{\circ} \mathrm{C}$ for $5 \mathrm{~s}$, was used to confirm the specificity of each reaction. Three independent reactions were performed to determine statistical significance. Target genes were normalized for relative quantification by the normalization factor derived from geometric means delta-Cq of PPIA, TBP, and HSPCB in Berkshire pigs; PPIA, TBP, RPL4, and RPS18 in Landrace pigs; PPIA and TBP in Duroc pigs; and PPIA, TOP2B, RPL4, and $R P S 18$ in Yorkshire pigs. The fold induction of HSD17B4 was analyzed by $2^{-\Delta \Delta C q}$ after determining $\triangle \Delta \mathrm{Cq}$ based on the relative difference between the experimental target and a control, which was extemporaneously selected based on the tissue with the lowest level of HSD17B4 expression. All experiments were performed according to guidelines of Minimum Information for Publication of Quantitative Real-Time PCR Experiments (MIQE) (Bustin et al., 2009). The significance between results was analyzed by the Student $t$-test with $\mathrm{P}<0.05$ being considered significant.

\section{Cell culture and myoblast differentiation}

Mouse $\mathrm{C} 2 \mathrm{C} 12$ myoblast cells were purchased from the ATCC (Manassas, VA, USA). C2C12 cells were maintained in Dulbecco's modified Eagle's medium (DMEM; Welgene, Daegu, Korea) supplemented with 10\% of fetal bovine serum (Gibco, Grand Island, NY, USA) in the presence of $100 \mathrm{U} / \mathrm{mL}$ penicillin and $100 \mu \mathrm{g} / \mathrm{mL}$ Streptomycin (Welgene) at $37^{\circ} \mathrm{C}$ in humidified atmosphere of air and $5 \% \mathrm{CO}_{2}$. For myogenesis, $\mathrm{C} 2 \mathrm{C} 12$ cells were switched to a differentiation medium containing DMEM supplemented with $2 \%$ heat-inactivated horse serum (Gibco) at $80 \%$ confluence for 8 days.

\section{Statistical analysis}

The general linear model procedure was used to analyze the association between genotypes and traits using the Statistical Software Package version 9.1.3 (SAS 2004). For statistical analysis, SNPs were selected based on high call rates $(>90 \%)$ and minor allele frequencies (MAFs) greater than 0.01 and Hardy-Weinberg equilibrium (HWE; P $>0.05$ ). We used a dominant model with the AA genotype versus the AG plus GG genotype, a recessive model with the GG genotype versus the AA plus AG genotype, and a codominant model with each genotype. The linear model was:

$$
\mathrm{y}_{i j k l m}=\mu+G_{i}+S_{\mathrm{j}}+P_{l}+e_{i j k l m}
$$

where $\mathrm{y}_{i j k l m}$ is the phenotypic value of the target trait, $\mu$ is the general mean, $G_{i}$ is the fixed effect of genotype $i, S_{j}$ is the fixed effect of $\operatorname{sex} j, P_{l}$ is the fixed effect of the slaughter period $l$, and $e_{i j k l m}$ is the term for random error. When significant differences were detected, the mean values were separated by the probability difference option. The results are reported as least square means \pm standard error.

Genetics and Molecular Research 15 (4): gmr15048970 


\section{RESULTS AND DISCUSSION}

\section{A non-synonymous HSD17B4 SNP in Berkshire liver}

The expression pattern of HSD17B4 in various tissues was determined. HSD17B4 was upregulated in the liver and kidney among all the tissues that were examined (Figure 1). All four pig breeds showed a similar tendency of HSD17B4 expression, although there were no significant differences between breeds. This result is supported by study showing that HSD17B4 mRNA expression was induced in many tissues including the kidney, liver, and lung (Su et al., 2004). In humans, the expression of HSD17B4 in the lung is higher than that in the liver and kidney, and HSD17B4 expression in the liver is higher than that in the kidney (Su et al., 2004). Upregulation of HSD17B4 in the liver and kidney may be inferred due to its function as regulator of steroid hormones. It is assumed that HSD17B4 affects $\beta$-oxidation of long fatty acids and steroid activity in peroxisomes. In addition, HSD17B4 is detected at high levels in the liver because of this function (Moe et al., 2008).
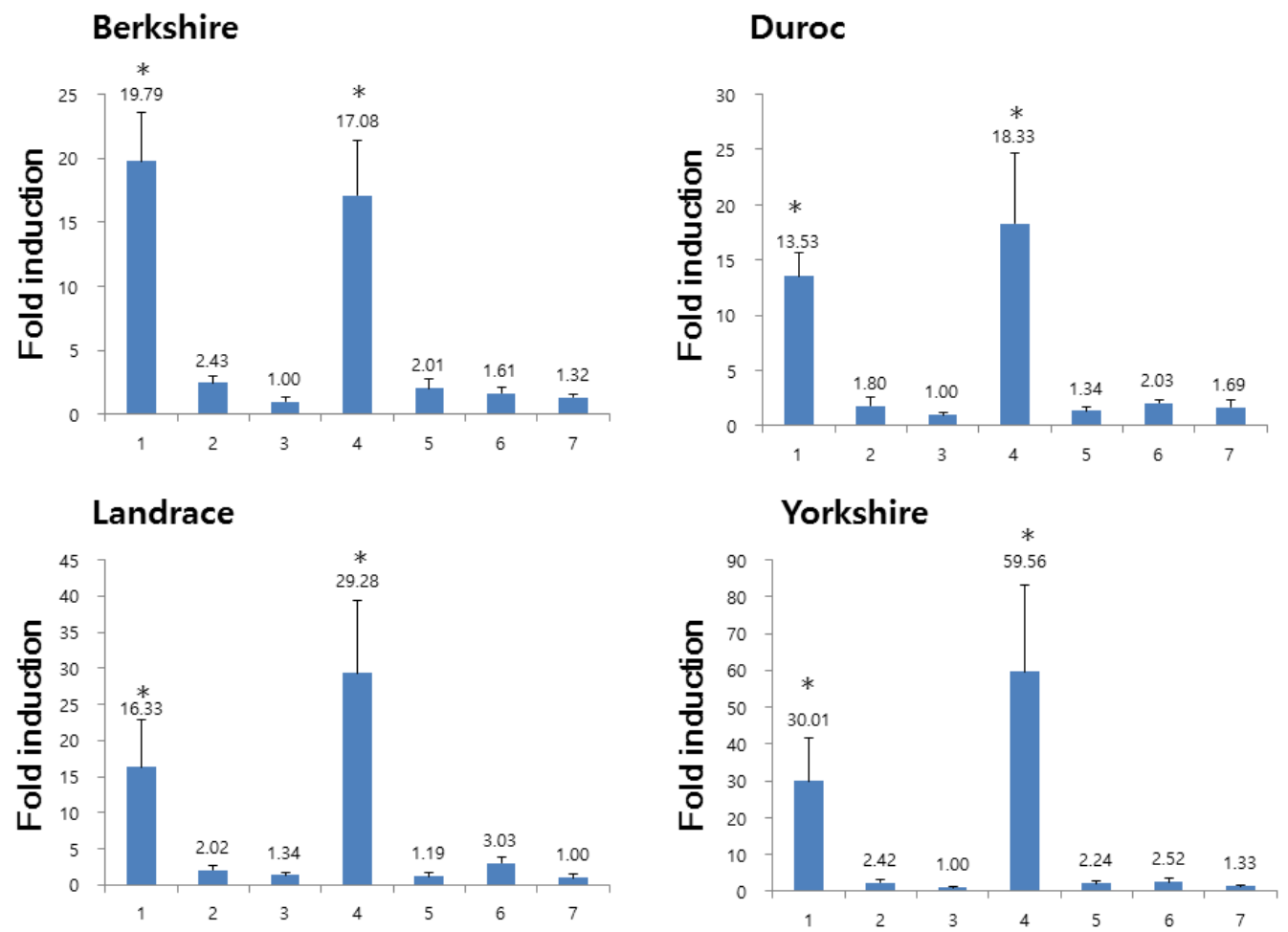

Figure 1. Relative expression of HSD17B4 from various tissues of four porcine breeds, as measured by RT-qPCR. The y-axis indicates fold induction of HSD17B4 mRNA compared to the lowest expression in each breed. *Significant difference in mRNA level between target tissue versus the lowest expression in each breed $(\mathrm{P}<0.05)$, as determined by the Student $t$-test. 1; liver, 2; stomach, 3; lung, 4; kidney, 5; large intestine, 6; small intestine, 7; spleen.

Genetics and Molecular Research 15 (4): gmr15048970 
Four SNPs were detected within the HSD17B4 gene in the liver from Berkshire pig. Among them, three were located in the 3'-untranslated region, but one was detected as an nsSNP of $c h r .128,825,976$, c. 2137 , I690V. This was same SNP found in rs81216713 from the dbSNP. It was located in the 22nd exon among a total of 23 exons in the corresponding SCP-2 domain. The SCP-2 domain mediates the activity of HSD17B4 through an interaction with its substrates, and plays an important role in the regulation of its enzymatic activity. Therefore, we chose this nsSNP among the four SNPs to analyze the association between genotype and meat-quality traits. The major allele was A and the minor allele was G. The MAF (0.3992), HWE (0.8308), and call rate (86.27\%) values were all suitable for SNP analysis (Table S2).

\section{Association between nsSNP and meat-quality traits}

Mice deficient in SCP-2 exhibit restricted functions related to degradation of long chain fatty acids or fatty acid derivatives (Seedorf et al., 1998). Therefore, it is assumed that a variant within this domain must affect the activities of fatty acid oxidation and steroid hormone in peroxisomes. Furthermore, it is hypothesized that such a phenomenon would affect meat quality due to changes in fatty acid accumulation and hormonal activity. In this regard, we analyzed the association between the HSD17B4 nsSNP and meat-quality traits. As shown in Table 2, the nsSNP of HSD17B4 was associated with carcass weight, backfat thickness, and drip loss. The GG genotype was associated with increased carcass weight and backfat thickness using the recessive model. However, the GG and AG genotypes in the dominant model demonstrated increased drip loss and the AG genotype showed a particularly large increase in drip loss.

Table 2. Association between meat-quality trait and a non-synonymous HSD17B4 SNP c. $2137 A>G$.

\begin{tabular}{|c|c|c|c|c|c|c|c|c|c|}
\hline \multirow{2}{*}{\multicolumn{3}{|c|}{$\begin{array}{l}\text { Model } \\
\text { Genotype }\end{array}$}} & \multicolumn{2}{|c|}{ Dominant } & \multicolumn{2}{|c|}{ Recessive } & \multicolumn{3}{|c|}{ Codominant } \\
\hline & & & $\begin{array}{c}\mathrm{GG}+\mathrm{AG} \\
(\mathrm{N}=240)\end{array}$ & $\begin{array}{c}\text { AA } \\
(\mathrm{N}=137)\end{array}$ & $\begin{array}{c}\text { GG } \\
(\mathrm{N}=61)\end{array}$ & $\begin{array}{c}\mathrm{AA}+\mathrm{AG} \\
(\mathrm{N}=316)\end{array}$ & $\begin{array}{c}\text { AA } \\
(\mathrm{N}=137)\end{array}$ & $\begin{array}{c}\mathrm{AG} \\
(\mathrm{N}=179)\end{array}$ & $\begin{array}{c}\text { GG } \\
(\mathrm{N}=61)\end{array}$ \\
\hline \multirow[t]{14}{*}{ Traits } & \multicolumn{2}{|l|}{ Carcass weight $(\mathrm{kg})$} & $85.93 \pm 5.99$ & $85.26 \pm 5.39$ & $87.20 \pm 5.76^{\mathrm{a}}$ & $85.39 \pm 5.75^{\mathrm{b}}$ & $85.26 \pm 5.39$ & $85.50 \pm 6.02$ & $87.20 \pm 5.76$ \\
\hline & \multicolumn{2}{|c|}{ Backfat thickness (mm) } & $25.00 \pm 5.01$ & $24.69 \pm 5.25$ & $25.98 \pm 4.58^{\mathrm{a}}$ & $24.68 \pm 5.17^{\mathrm{b}}$ & $24.69 \pm .25$ & $24.67 \pm 5.11$ & $25.98 \pm 4.58$ \\
\hline & \multirow{3}{*}{ Meat color } & CIE L & $48.63 \pm 2.94$ & $48.64 \pm 2.87$ & $48.51 \pm 3.32$ & $48.66 \pm 2.83$ & $48.64 \pm 2.87$ & $48.67 \pm 2.81$ & $48.51 \pm 3.32$ \\
\hline & & $\mathrm{CIE}$ a & $6.18 \pm 1.03$ & $6.15 \pm 1.15$ & $6.24 \pm 0.97$ & $6.16 \pm 1.09$ & $6.15 \pm 1.15$ & $6.17 \pm 1.05$ & $6.24 \pm 0.97$ \\
\hline & & $\mathrm{CIE} \mathrm{b}$ & $2.78 \pm 1.02$ & $2.90 \pm 1.15$ & $2.93 \pm 1.02$ & $2.80 \pm 1.08$ & $2.90 \pm 1.15$ & $2.72 \pm 1.02$ & $2.93 \pm 1.02$ \\
\hline & \multicolumn{2}{|l|}{ Drip loss (\%) } & $4.78 \pm 2.03^{\mathrm{a}}$ & $4.27 \pm 1.76^{\mathrm{b}}$ & $4.59 \pm 2.13$ & $4.59 \pm 1.92$ & $4.27 \pm 1.76^{\mathrm{b}}$ & $4.85 \pm 2.01^{\mathrm{a}}$ & $4.59 \pm 2.13^{\mathrm{ab}}$ \\
\hline & \multicolumn{2}{|l|}{ Cooking loss (\%) } & $27.74 \pm 3.42$ & $27.32 \pm 3.90$ & $27.76 \pm 2.90$ & $27.56 \pm 3.73$ & $27.32 \pm 3.90$ & $27.74 \pm 3.59$ & $27.76 \pm 2.90$ \\
\hline & \multirow{4}{*}{$\begin{array}{l}\text { Chemical } \\
\text { composition (\%) }\end{array}$} & Collagen & $0.89 \pm 0.13$ & $0.89 \pm 0.13$ & $0.88 \pm 0.14$ & $0.89 \pm 0.13$ & $0.89 \pm 0.13$ & $0.89 \pm 0.13$ & $0.88 \pm 0.14$ \\
\hline & & Fat & $2.83 \pm 1.26$ & $2.81 \pm 1.11$ & $2.92 \pm 1.27$ & $2.80 \pm 1.16$ & $2.81 \pm 1.11$ & $2.90 \pm 1.20$ & $2.92 \pm 1.27$ \\
\hline & & Moisture & $75.52 \pm 0.92$ & $75.54 \pm 0.80$ & $75.48 \pm 0.98$ & $75.53 \pm 0.85$ & $75.54 \pm 0.80$ & $75.53 \pm 0.90$ & $75.48 \pm 0.98$ \\
\hline & & Protein & $23.83 \pm 0.70$ & $23.80 \pm 0.74$ & $23.82 \pm 0.61$ & $23.82 \pm 0.74$ & $23.80 \pm 0.74$ & $23.83 \pm 0.73$ & $23.82 \pm 0.61$ \\
\hline & \multicolumn{2}{|c|}{\begin{tabular}{|l} 
Water-holding capacity (\%) \\
\end{tabular}} & $57.97 \pm 2.50$ & $58.15 \pm 2.80$ & $58.36 \pm 2.616$ & $57.97 \pm 2.61$ & $58.15 \pm 2.80$ & $57.84 \pm 2.45$ & $58.36 \pm 2.62$ \\
\hline & \multicolumn{2}{|c|}{ Warner-Bratzler shear force $(\mathrm{N})$} & $28.714 \pm 6.566$ & $28.028 \pm 7.056$ & $28.42 \pm 5.88$ & $28.42 \pm 6.86$ & $28.028 \pm 7.056$ & $28.812 \pm 6.762$ & $28.42 \pm 5.88$ \\
\hline & \multicolumn{2}{|c|}{ Post-mortem pH $24 \mathrm{~h}$} & $5.82 \pm 0.21$ & $5.84 \pm 0.22$ & $5.83 \pm 0.22$ & $5.83 \pm 0.21$ & $5.84 \pm 0.22$ & $5.82 \pm 0.20$ & $5.83 \pm 0.22$ \\
\hline
\end{tabular}

${ }^{\mathrm{a}, \mathrm{b}}$ Least square means in the same row with different superscript letters differ significantly $(\mathrm{P}<0.05)$ in the genotypes.

In the analyses between meat-quality traits and gender, there was only a significant relationship with respect to carcass weight by using the codominant model in gilts, where the GG genotype showed increased carcass weight (Table 3). Interestingly, carcass weight was high mainly in females depending on the mutated allelic GG. However, while not significantly different, backfat thickness tended to be high in all genotypes in barrows. Generally, castration reduces the stimulation of lean growth by removing natural anabolic androgens (Gispert et al., 2010). Therefore, uncastrated males have leaner yields and higher feed efficiency than that by barrows. Gilts had thinner backfat thickness and lower crude fat content than did barrows,

Genetics and Molecular Research 15 (4): gmr15048970 
whereas crude protein content was higher than that for barrows (Table S3). Therefore, we believe that Berkshire gilts exhibit higher economic efficiency with respect to meat quality than that by barrows.

\begin{tabular}{|c|c|c|c|c|c|c|c|c|c|}
\hline \multirow{3}{*}{\multicolumn{2}{|c|}{$\begin{array}{l}\text { Model } \\
\text { Gender } \\
\text { Genotype }\end{array}$}} & \multirow{2}{*}{\multicolumn{4}{|c|}{ Dominant }} & \multirow{2}{*}{\multicolumn{4}{|c|}{ Recessive }} \\
\hline & & & & & & & & & \\
\hline & & \multicolumn{2}{|c|}{\begin{tabular}{|c|c|c|}
\multicolumn{2}{c}{ barrow } \\
$\mathrm{GG}+\mathrm{AG}$ & $\mathrm{AA}$ \\
\end{tabular}} & $\begin{array}{l}\mathrm{GG}+\mathrm{AG} \\
(\mathrm{N}=112)\end{array}$ & $\begin{array}{c}\mathrm{AA} \\
(\mathrm{N}=79)\end{array}$ & $\begin{array}{c}\mathrm{GG} \\
(\mathrm{N}=35)\end{array}$ & $\begin{array}{l}\mathrm{AA}+\mathrm{AG} \\
(\mathrm{N}=151) \\
\end{array}$ & $\begin{array}{c}\mathrm{GG} \\
(\mathrm{N}=26)\end{array}$ & $\begin{array}{l}\mathrm{AA}+\mathrm{AG} \\
(\mathrm{N}=165)\end{array}$ \\
\hline \multirow{2}{*}{\multicolumn{2}{|c|}{$\begin{array}{l}\text { Carcass weight }(\mathrm{kg}) \\
\text { Backfat thickness }(\mathrm{mm})\end{array}$}} & $85.90 \pm 6.13$ & $85.25 \pm 6.05$ & $85.96 \pm 5.85$ & $85.25 \pm 4.88$ & $86.34 \pm 6.05$ & $85.55 \pm 6.12$ & & $85.25 \pm 5.40^{6}$ \\
\hline \multirow{2}{*}{\multicolumn{2}{|c|}{$\begin{array}{l}\text { Backfat hickness }(\mathrm{mm}) \\
\text { Meat color }\end{array}$}} & $27.07 \pm 4.48$ & $\begin{array}{l}27.33 \pm 4.92 \\
490+2.70 \\
490\end{array}$ & $22.63 \pm 4.52$ & $22.76 \pm 4.63$ & $27.66 \pm 4.35$ & $27.03 \pm 4.67$ & 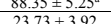 & $22.52 \pm 4.64$ \\
\hline & $\begin{array}{ll}\mathrm{CIEL} \\
\mathrm{CIE}\end{array}$ & $\begin{array}{l}49.13 \pm 2.95 \\
6.14 \pm 1.01\end{array}$ & $49.40 \pm 2.7$ & $\frac{48.05 \pm 2.83}{6.23+1.05}$ & $\frac{48.09 \pm 2.88}{6.12+1.24}$ & $\begin{array}{l}49.42 \pm 3.54 \\
607 \pm 0.99\end{array}$ & $49.16 \pm 2.71$ & & $\begin{array}{l}48.19 \pm 2.87 \\
615+16\end{array}$ \\
\hline $\begin{array}{l}\text { Meat color } \\
\end{array}$ & $\frac{\mathrm{CIE} a}{\mathrm{CIE} b}$ & $\frac{6.14 \pm 1.01}{2.69 \pm 1.05}$ & $\frac{6.20 \pm 1.01}{2.99 \pm 1.00}$ & $\frac{6.23 \pm 1.05}{2.87 \pm 0.98}$ & $\frac{6.1221 .24}{2.83 \pm 1.24}$ & $\frac{6.07 \pm 0.99}{2.87 \pm 1.14}$ & \multirow{2}{*}{$\begin{array}{l}\frac{2.76 \pm 1.02}{4.77+2.12} \\
\end{array}$} & $\begin{array}{c}4.28 \pm .258 \\
6.46 \pm 0.90 \\
\end{array}$ & $\frac{6.15 \pm 1.16}{2.83 \pm 1.13}$ \\
\hline \multirow{2}{*}{\multicolumn{2}{|c|}{$\begin{array}{l}\text { Drip loss (\%) } \\
\text { Cooking loss (\%) }\end{array}$}} & $5.02 \pm 2.19$ & $4.39 \pm 1.99$ & $4.5 \pm 1.81$ & $4.18 \pm 1.58$ & $5.06 \pm 2.25$ & & $3.96 \pm 1.80$ & $\frac{.30 x 1.13}{4.43 \pm 1.71}$ \\
\hline & & $27.69 \pm 3.55$ & $27.52 \pm 3.75$ & $27.8 \pm 3.28$ & $27.17 \pm 4.02$ & $28.02 \pm 2.83$ & $27.55 \pm 3.76$ & $27.39 \pm 3.01$ & $27.56 \pm 3.7$ \\
\hline $\begin{array}{l}\text { Chemical } \\
\text { composition (\%) }\end{array}$ & $\begin{array}{l}\text { Collagen } \\
\text { Fat }\end{array}$ & $\frac{0.87 \pm 0.14}{3.32 \pm 107}$ & $\begin{array}{l}0.87 \pm 0.13 \\
3.25 \pm 1.31\end{array}$ & $\begin{array}{l}0.90 \pm 0.12 \\
2.350 .88\end{array}$ & $\begin{array}{l}0.91 \pm 0.13 \\
249+1.04\end{array}$ & $0.87 \pm 0.16$ & $\frac{0.87 \pm 0.13}{3.23 \pm 12}$ & $\frac{0.88 \pm 0.12}{2.36 \pm 0.76}$ & $\begin{array}{l}0.91 \pm 0.13 \\
24 \pm 0.97\end{array}$ \\
\hline composition (\%) & Moisture & $\frac{2.25 \pm 1.07}{75.35 \pm 1.03}$ & $75.43 \pm 0.79$ & $\frac{2.35 \pm 0.88}{75.70 \pm 0.72}$ & $\begin{array}{l}2.491 .04 \\
75.62 \pm 0.79\end{array}$ & $\begin{array}{l}\frac{3.34 \pm 1.41}{75.26 \pm 1.11} \\
\end{array}$ & $\begin{array}{l}3.23 \pm 1.2 \\
75.4 \pm 0.93 \\
\end{array}$ & $\begin{array}{l}2.36 \pm 0.76 \\
75.78 \pm 0.70\end{array}$ & $\begin{array}{l}\frac{2.44 \pm 0.97}{75.65 \pm 0.76} \\
\end{array}$ \\
\hline Water-holdingo & $\begin{array}{l}\text { Protein } \\
(0)\end{array}$ & $\begin{array}{l}23.62 \pm 0.67 \\
556+246\end{array}$ & $\frac{23.57 \pm 0.72}{579+276}$ & $\begin{array}{l}24.07 \pm 0.67 \\
58.39+249\end{array}$ & $\begin{array}{l}23.97 \pm 0.72 \\
58.33+284\end{array}$ & $\begin{array}{l}23.66 \pm 0.62 \\
5709+248\end{array}$ & $\begin{array}{l}23.59 \pm 0.7 \\
5.63 \pm 257\end{array}$ & \begin{tabular}{|l|l|l}
$24.02 \pm 0.55$ \\
$585+276$
\end{tabular} & $\begin{array}{l}24.03 \pm 0.71 \\
5820+21\end{array}$ \\
\hline $\begin{array}{l}\text { Ware-ronding capa a } \\
\text { Warner-Bratzler she }\end{array}$ & force (N) & $\frac{27.0 \pm 2.40}{27.34 \pm 5.98}$ & $26.61 \pm 2.10$ & $\frac{30.59 \pm 2.49}{30.18 \pm 6.86}$ & $\begin{array}{l}\frac{58.33 \pm 2.84}{29.00 \pm 9.11} \\
\end{array}$ & $\frac{57.992 .48}{28.13 \pm 5.98}$ & $\begin{array}{l}27.63 \pm .257 \\
26.95 \pm 6.47\end{array}$ & $\begin{array}{l}58.85 \pm 2.76 \\
28.71+5.68\end{array}$ & $\frac{58.29 \pm 2.61}{29.89 \pm 6.96}$ \\
\hline Post-mortem pH 24 & & $5.82 \pm 0.23$ & $5.85 \pm 0.25$ & $5.82 \pm 0.18$ & $5.83 \pm 0.18$ & $5.83 \pm 0.26$ & $5.83 \pm 0.23$ & $5.83 \pm 0.13$ & $\frac{19.090 .00}{5.82 \pm 0.18}$ \\
\hline & & & & & & & & & \\
\hline$\frac{\text { Gender }}{\text { Genotype }}$ & & & & rrow & & & & & \\
\hline Genotype & & $\begin{array}{c}\mathrm{AA} \\
(\mathrm{N}=58)\end{array}$ & & $\begin{array}{l}A G \\
A=93) \\
A\end{array}$ & $\begin{array}{c}\mathrm{GG} \\
(\mathrm{NG}=35)\end{array}$ & $\begin{array}{c}\mathrm{AA} \\
(\mathrm{N}=79)\end{array}$ & & & $\begin{array}{l}\mathrm{GG} \\
(\mathrm{N}=26)\end{array}$ \\
\hline Carcass weight $(\mathrm{kg})$ & & $85.26 \pm 6.05$ & & $3 \pm 6.18$ & $\frac{86.34 \pm 6.05}{2.34}$ & $85.25 \pm 4.88$ & 85.24 & & $\frac{88.35 \pm 5.25^{\mathrm{a}}}{872}$ \\
\hline $\begin{array}{l}\text { Backfat thic| } \\
\text { Meatcolor }\end{array}$ & & $27.33 \pm 4.92$ & & & & $22.76 \pm 4.63$ & 22.3 & & $23.73 \pm 3.92$ \\
\hline Meat color & $\begin{array}{ll}\mathrm{CIEL} \\
\mathrm{CIF}\end{array}$ & $\frac{49.40 \pm 2.69}{6.2 \pm 1.01}$ & & $\begin{array}{l}2 \pm 2.72 \\
5 \pm 1.02\end{array}$ & $\begin{array}{l}49.42 \pm 3.54 \\
6.07+0.99\end{array}$ & $\frac{48.09 \pm 2.88}{6.12 \pm .24}$ & $\frac{48.29}{6.17}$ & & $\frac{47.28 \pm 2.58}{646+0.9}$ \\
\hline & CIE b & $2.99 \pm 1.00$ & & $2 \pm 1.01$ & $2.87 \pm 1.14$ & $2.83 \pm 1.24$ & 2.82 & & $\frac{0.400 .9}{3.01 \pm 0.84}$ \\
\hline $\begin{array}{l}\text { Drip loss (\%) } \\
\end{array}$ & & $4.39 \pm$ & & $1 \pm 2.18$ & $5.06 \pm$ & $4.18 \pm 1.56$ & 4.67 & & $3.96 \pm 1.8$ \\
\hline Cooking loss (\%) & & $27.52 \pm 3.75$ & & $6 \pm 3.79$ & $28.02 \pm 2.83$ & $27.17 \pm 4.02$ & 27.92 & & $27.39 \pm 3.01$ \\
\hline $\begin{array}{l}\text { Chemical } \\
\text { composition (\%) }\end{array}$ & Collagen & $0.87 \pm 0.13$ & & $7 \pm 0.13$ & $0.87 \pm 0.16$ & $0.91 \pm 0.13$ & 0.91 & & $0.88 \pm 0.12$ \\
\hline composition (\%) & Fat & $\frac{3.23 \pm 1.07}{75.43 \pm 0.79}$ & & $\frac{2 \pm 1.28}{8 \pm 1.01}$ & $\frac{3.34 \pm 1.41}{75.26 \pm 1.11}$ & $\begin{array}{r}2.49 \pm 1.04 \\
75.62+0.79\end{array}$ & $\frac{2.34}{75.68}$ & & $\frac{2.36 \pm 0.76}{75.78+0.70}$ \\
\hline & $\begin{array}{l}\text { Mrotsine } \\
\text { Protin }\end{array}$ & $23.57 \pm 0.72$ & & $\begin{array}{l}8 \pm 1.01 \\
0.0 .68\end{array}$ & & $\frac{15.02 \pm 0.19}{23.97 \pm 0.72}$ & & & $\frac{1.18 \pm 0.0}{24.02 \pm 0.55}$ \\
\hline Water-holding capa & $y(\%)$ & $57.91 \pm 2.76$ & & $5 \pm 2.45$ & $57.99 \pm 2.48$ & $58.33 \pm 2.84$ & 58.26 & & $58.85 \pm 2.76$ \\
\hline$\frac{\text { Warner-Bratzler she }}{\text { Postamortem } \mathrm{pH}^{2}}$ & fo & $\frac{26.66 \pm 7.35}{5.85 \pm 0.25}$ & & $\frac{5 \pm 5.98}{2 \pm 0.22}$ & $\frac{28.126 \pm 5.98}{5.83 \pm 0.26}$ & $\frac{29.90 \pm 6.66}{5.83 \pm 0.18}$ & $\frac{30.58}{5.82}$ & & $\frac{28.71 \pm 5.68}{583 \pm 0.13}$ \\
\hline
\end{tabular}

a,b Least square means in the same row with different superscript letters differ significantly $(\mathrm{P}<0.05)$ in the genotypes.

SCP-2 forms a tunnel structure composed of $5 \alpha$-helix and $5 \beta$-sheets (Haapalainen et al., 2001). The HSD17B4 nsSNP is located in $\beta$-sheet IV. Among the amino acid residues of $\beta$-sheet IV, I689 and L691 make up the inside of the tunnel (Haapalainen et al., 2001). Results from the nsSNP analysis of HSD17B4 performed in this study indicated that I690 is one of the residues forming the tunnel structure between I689 and L691. As the HSD17B4 nsSNP exists in $\beta$-sheet IV, it is assumed to induce a minor change in the substrate-binding ability of HSD17B4, which could modify steroid activity. Consequently, the HSD17B4 nsSNP could affect carcass weight, backfat thickness, and drip loss. In the future, the structural difference between wild-type and mutant HSD17B4 should be investigated to prove the effects of polymorphisms on meat quality.

There is a close relationship between low birth weight and decreased survival or low postnatal growth rates. In addition, pigs with low birth weight have low lean meat percentage at slaughter (Gispert et al., 2010). Furthermore, low birth weight was believed to result from decreased prenatal myogenesis (Gispert et al., 2010). Therefore, we performed myogenesis with the $\mathrm{C} 2 \mathrm{C} 12$ mouse myoblast cell line. Differentiation was generated by addition of $2 \%$ horse serum in the culture media and myogenesis was confirmed by investigating marker genes for myogenesis such as MyoD, MyoG, and MyHC-2B. Early stage markers MyoD and MyoG increased at day 2 of differentiation whereas the late stage marker, MyHC-2B, was

Genetics and Molecular Research 15 (4): gmr15048970 
induced at day 6 of differentiation. The mRNA expression level of HSD17B4 was determined during myogenesis. As shown in Figure 2, mRNA expression of HSD17B4 was significantly upregulated during the early stage of myogenesis and this elevated expression was maintained until the late stage of myogenesis. The marker genes for myogenesis accurately identified myogenesis in $\mathrm{C} 2 \mathrm{C} 12$ cells upon addition of serum. We believe that the induction of HSD17B4 at day 2 of differentiation may play a role in early myogenesis, which could contribute to acceleration of postnatal growth rate and percentage of lean growth.

A
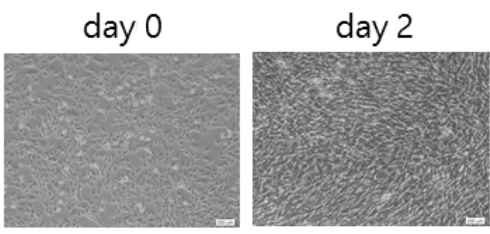

day 6

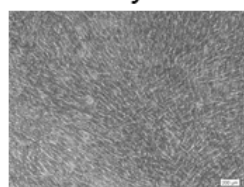

C

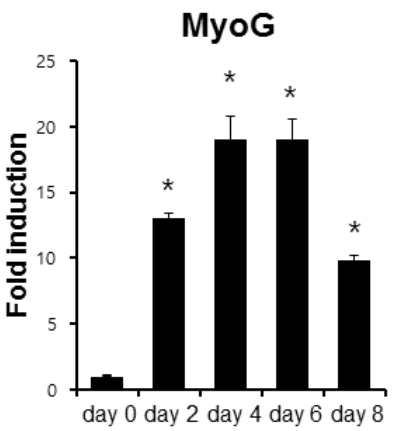

day 8

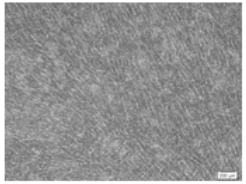

D day 4

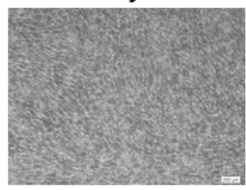

B

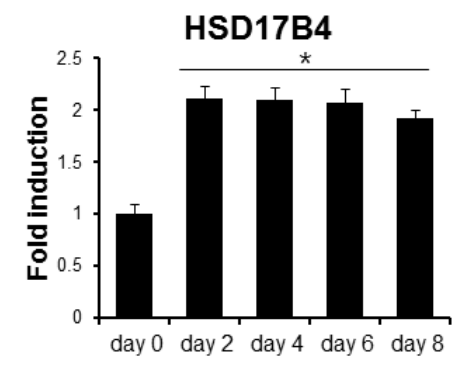

$\mathrm{E}$

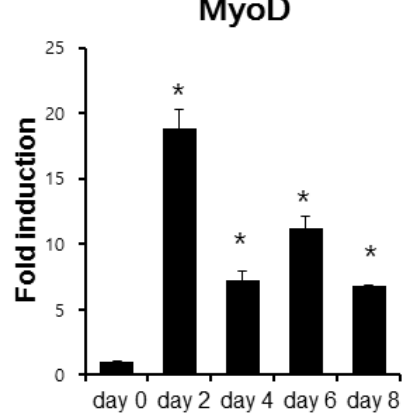

MyHC-2B

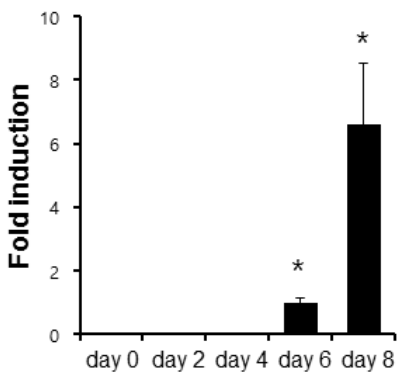

Figure 2. RT-qPCR analysis of HSD17B4, MyoD, MyoG, and MyHC-2B. C2C12 cells were cultured with DMEM. Myogenesis was initiated by addition of $2 \%$ horse serum at $80 \%$ confluence. Cells were observed under the microscope (A). The mRNA expression of HSD17B4 was measured by RT-qPCR. The fold-change of HSD17B4 during myogenesis was measured. GAPDH was used as loading control (B). mRNA expression of myogenesis markers (MyoD, MyoG, and MyHC-2B) was performed by RT-qPCR. GAPDH was used as loading control (C-E). The statistical analysis was performed with the Student $t$-test. Data are reported as means $\pm \mathrm{SD}$. $* \mathrm{P}<0.05$ vs control.

\section{CONCLUSIONS}

Analysis of HSD17B4 expression in various tissues of four pig breeds revealed that it was highly expressed in the liver and kidney. An nsSNP of HSD17B4 from Berkshire liver was found in the SCP-2 domain and demonstrated a significant association with carcass weight, backfat thickness, and drip loss. HSD17B4 may play a crucial role in early myogenesis because the expression of HSD17B4 mRNA was significantly high at this stage. Induction of HSD17B4 mRNA at the early stage of myogenesis could accelerate myogenesis, thereby 
increasing the survival rate and percentage of lean meat. Thus, characterizing the expression of genes associated with myogenesis may have great significance for improving meat quality. Additionally, the HSD17B4 nsSNP might be employed as a molecular marker to evaluate meat quality.

\section{ACKNOWLEDGMENTS}

Research supported by grants from the Priority Research Centers Program (\#20110022965) through the National Research Foundation of Korea (NRF) funded by the Ministry of Education, Science and Technology, from the Export Promotion Technology Development Program (\#313012-05) of Ministry of Food, Agriculture, Forestry and Fisheries, Republic of Korea, and by the Gyeongnam National University of Science and Technology (grant 2015).

\section{REFERENCES}

AOAC (2006). Association of Official Analytical Chemists. 14th edn. AOAC Inc., Arlington.

Baker ME (2001). Evolution of 17beta-hydroxysteroid dehydrogenases and their role in androgen, estrogen and retinoid action. Mol. Cell. Endocrinol. 171: 211-215. http://dx.doi.org/10.1016/S0303-7207(00)00414-7

Breitling R, Marijanović Z, Perović D and Adamski J (2001). Evolution of 17beta-HSD type 4, a multifunctional protein of beta-oxidation. Mol. Cell. Endocrinol. 171: 205-210. http://dx.doi.org/10.1016/S0303-7207(00)00415-9

Bustin SA, Benes V, Garson JA, Hellemans J, et al. (2009). The MIQE guidelines: minimum information for publication of quantitative real-time PCR experiments. Clin. Chem. 55: 611-622. http://dx.doi.org/10.1373/clinchem.2008.112797

Chai YL, Ma HM and Jiang J (2015). Molecular characterization, tissue expression profile and SNP analysis of porcine GLP2R. Genet. Mol. Res. 14: 12931-12941. http://dx.doi.org/10.4238/2015.October.21.14

Cho ES, Lee KT, Choi JW, Jeon HJ, et al. (2015a). Novel SNPs in the growth arrest and DNA damage-inducible protein 45 alpha gene (GADD45A) associated with meat quality traits in Berkshire pigs. Genet. Mol. Res. 14: 8581-8588. http://dx.doi.org/10.4238/2015.July.31.6

Cho HR, Ha J, Kwon SG, Hwang JH, et al. (2015b). Single-Nucleotide Polymorphisms in Pig EPHX1 Gene are Associated with Pork Quality Traits. Anim. Biotechnol. 26: 237-242. http://dx.doi.org/10.1080/10495398.2015.1005215

Colles SM, Woodford JK, Moncecchi D, Myers-Payne SC, et al. (1995). Cholesterol interaction with recombinant human sterol carrier protein-2. Lipids 30: 795-803. http://dx.doi.org/10.1007/BF02533954

Dansen TB, Westerman J, Wouters FS, Wanders RJ, et al. (1999). High-affinity binding of very-long-chain fatty acylCoA esters to the peroxisomal non-specific lipid-transfer protein (sterol carrier protein-2). Biochem. J. 339: 193-199. http://dx.doi.org/10.1042/bj3390193

Ferreyra RG, Burgardt NI, Milikowski D, Melen G, et al. (2006). A yeast sterol carrier protein with fatty-acid and fattyacyl-CoA binding activity. Arch. Biochem. Biophys. 453: 197-206. http://dx.doi.org/10.1016/j.abb.2006.06.024

García FL, Szyperski T, Dyer JH, Choinowski T, et al. (2000). NMR structure of the sterol carrier protein-2: implications for the biological role. J. Mol. Biol. 295: 595-603. http://dx.doi.org/10.1006/jmbi.1999.3355

Gispert M, Angels Oliver M, Velarde A, Suarez P, et al. (2010). Carcass and meat quality characteristics of immunocastrated male, surgically castrated male, entire male and female pigs. Meat Sci. 85: 664-670. http://dx.doi.org/10.1016/j. meatsci.2010.03.021

Haapalainen AM, van Aalten DM, Meriläinen G, Jalonen JE, et al. (2001). Crystal structure of the liganded SCP-2-like domain of human peroxisomal multifunctional enzyme type 2 at 1.75 A resolution. J. Mol. Biol. 313: 1127-1138. http://dx.doi.org/10.1006/jmbi.2001.5084

Jung WY, Kwon SG, Son M, Cho ES, et al. (2012). RNA-Seq approach for genetic improvement of meat quality in pig and evolutionary insight into the substrate specificity of animal carbonyl reductases. PLoS One 7: e42198. http://dx.doi. org/10.1371/journal.pone.0042198

Kaufmann M, Carstensen J, Husen B and Adamski J (1995). The tissue distribution of porcine 17 beta-estradiol dehydrogenase and its induction by progesterone. J. Steroid Biochem. Mol. Biol. 55: 535-539. http://dx.doi. org/10.1016/0960-0760(95)00203-0

Kristensen L and Purslow PP (2001). The effect of ageing on the water-holding capacity of pork: role of cytoskeletal proteins. Meat Sci. 58: 17-23. http://dx.doi.org/10.1016/S0309-1740(00)00125-X

Genetics and Molecular Research 15 (4): gmr15048970 
Moe M, Meuwissen T, Lien S, Bendixen C, et al. (2007). Gene expression profiles in testis of pigs with extreme high and low levels of androstenone. BMC Genomics 8: 405. http://dx.doi.org/10.1186/1471-2164-8-405

Moe M, Lien S, Bendixen C, Hedegaard J, et al. (2008). Gene expression profiles in liver of pigs with extreme high and low levels of androstenone. BMC Vet. Res. 4: 29. http://dx.doi.org/10.1186/1746-6148-4-29

Moeller G and Adamski J (2009). Integrated view on 17beta-hydroxysteroid dehydrogenases. Mol. Cell. Endocrinol. 301: 7-19. http://dx.doi.org/10.1016/j.mce.2008.10.040

Park SJ, Kwon SG, Hwang JH, Park DH, et al. (2015). Selection of appropriate reference genes for RT-qPCR analysis in Berkshire, Duroc, Landrace, and Yorkshire pigs. Gene 558: 152-158. http://dx.doi.org/10.1016/j.gene.2014.12.052

Rozen S and Skaletsky H (2000). Primer3 on the WWW for general users and for biologist programmers. Methods Mol. Biol. 132: 365-386.

Seedorf U, Raabe M, Ellinghaus P, Kannenberg F, et al. (1998). Defective peroxisomal catabolism of branched fatty acyl coenzyme A in mice lacking the sterol carrier protein-2/sterol carrier protein-x gene function. Genes Dev. 12: 11891201. http://dx.doi.org/10.1101/gad.12.8.1189

Stolowich NJ, Frolov A, Atshaves B, Murphy EJ, et al. (1997). The sterol carrier protein-2 fatty acid binding site: an NMR, circular dichroic, and fluorescence spectroscopic determination. Biochemistry 36: 1719-1729. http://dx.doi. org/10.1021/bi962317a

Su AI, Wiltshire T, Batalov S, Lapp H, et al. (2004). A gene atlas of the mouse and human protein-encoding transcriptomes. Proc. Natl. Acad. Sci. USA 101: 6062-6067. http://dx.doi.org/10.1073/pnas.0400782101

Wu F, Zuo JJ, Yu QP, Zou SG, et al. (2015). Effect of skeletal muscle fibers on porcine meat quality at different stages of growth. Genet. Mol. Res. 14: 7873-7882. http://dx.doi.org/10.4238/2015.July.14.13

\section{Supplementary material}

Table S1. Oligonucleotides used in this study.

Table S2. Summary of SNP genotyping analyses.

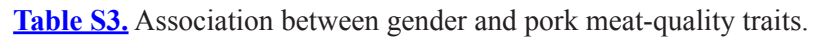

Genetics and Molecular Research 15 (4): gmr15048970 